University of Nebraska - Lincoln

DigitalCommons@University of Nebraska - Lincoln

Roman L. Hruska U.S. Meat Animal Research

U.S. Department of Agriculture: Agricultural Center

Research Service, Lincoln, Nebraska

2001

\title{
Characterization of Uterine Epidermal Growth Factor During Early Pregnancy in Pigs
}

J. G. Kim

USDA-ARS

J. L. Vallet

USDA-ARS

R. K. Christenson

USDA-ARS

Follow this and additional works at: https://digitalcommons.unl.edu/hruskareports

Kim, J. G.; Vallet, J. L.; and Christenson, R. K., "Characterization of Uterine Epidermal Growth Factor During Early Pregnancy in Pigs" (2001). Roman L. Hruska U.S. Meat Animal Research Center. 239.

https://digitalcommons.unl.edu/hruskareports/239

This Article is brought to you for free and open access by the U.S. Department of Agriculture: Agricultural Research Service, Lincoln, Nebraska at DigitalCommons@University of Nebraska - Lincoln. It has been accepted for inclusion in Roman L. Hruska U.S. Meat Animal Research Center by an authorized administrator of DigitalCommons@University of Nebraska - Lincoln. 

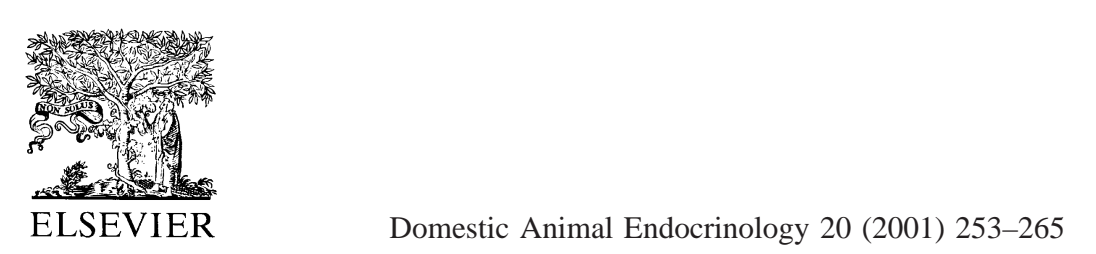

DOMESTIC

ANIMAL

ENDOCRINOLOGY

\title{
Characterization of uterine epidermal growth factor during early pregnancy in pigs is $^{2}$
}

\author{
J.G. Kim, J.L. Vallet, R.K. Christenson* \\ USDA-ARS, Roman L. Hruska U.S. Meat Animal Research Center, P. O. Box 166, \\ Clay Center, NE 68933-0166, USA
}

Received 30 November 2000; accepted 6 February 2001

\begin{abstract}
Genomic research has identified a quantitative trait locus for uterine capacity, a component trait contributing to litter size, on porcine chromosome 8. The epidermal growth factor (EGF) gene, on porcine chromosome 8, may influence uterine capacity because of its growth-promoting activities. Using reverse transcription-polymerase chain reaction (PCR) and iterative screening of a porcine reproductive tissue cDNA library, 4932 bp cDNA sequence coding for porcine EGF precursor was obtained. The predicted protein sequence of the EGF precursor contained 1214 amino acids, similar to human EGF precursor (1207 amino acids, 81\% identity). Curiously, the sequence of the mature peptide was less homologous between species than other regions of EGF precursor. The presence of conserved regions outside the mature peptide may suggest that these regions are functionally important. Expression of EGF mRNA in the endometrium of White crossbred gilts ( $n=3$ to 5 each) was determined by Northern blotting using $20 \mu \mathrm{g}$ of total RNA from endometrium of D 10, 13, and 15 cyclic, and D 10, 13, 15, 20, 30, and 40 of pregnant gilts. A 3342 bp probe from EGF precursor was used. The bands corresponding to EGF mRNA were quantified by densitometry and results were analyzed by ANOVA. EGF mRNA expression decreased significantly from D 13 to 15 of the cycle and pregnancy $(\mathrm{P}=0.04)$, and from $\mathrm{D} 30$ to 40 of pregnancy $(\mathrm{P}=0.01)$. These findings show that EGF mRNA expression is temporally regulated during the cycle and early pregnancy, and this pattern of gene expression may be important during early conceptus development. (C) 2001 Elsevier Science Inc. All rights reserved.
\end{abstract}

4h Mention of trade names or commercial products in this article is solely for the purpose of providing specific information and does not imply recommendation or endorsement by the U.S. Department of Agriculture.

* Corresponding author. Tel.: +1-402-762-4192; fax: +1-402-762-4382.

E-mail address: christenson@email.marc.usda.gov (R.K. Christenson).

0739-7240/01/\$ - see front matter (C) 2001 Elsevier Science Inc. All rights reserved. PII: S0739-7240(01)00097-2

This article is a U.S. government work, and is not subject to copyright in the United States. 


\section{Introduction}

Epidermal growth factor (EGF) is a 53-amino acid polypeptide that has been reported to stimulate epithelial cell growth. EGF and EGF receptor mRNA expression have been shown in the porcine conceptus by reverse transcription-PCR (RT-PCR) [1]. In the endometrium, EGF mRNA expression has been shown by RT-PCR to be higher on D 6 than D 1 of cyclic and pregnant pigs [2]. The presence of EGF protein in uterine fluid [3] and of EGF receptors in endometrium [4] has also been reported. These data suggest a role for EGF in the development of porcine conceptus and endometrium.

Uterine capacity is a component trait contributing to litter size in swine [5], and direct selection for uterine capacity has significantly increased uterine capacity and associated farrowing traits in swine [6,7]. A quantitative trait locus (QTL) for uterine capacity was identified on the long arm of chromosome 8 near $71 \mathrm{cM}$ [8]. This region is near the known location of the gene for EGF precursor [9]. Thus, because of its location and its potential effect on conceptus or endometrial growth, EGF gene is a candidate for the previously reported uterine capacity QTL on chromosome 8.

Partial genomic and cDNA sequences of porcine EGF precursor [10,11], including the coding region of the mature protein, have been reported. However, the entire coding region of the porcine EGF precursor has not been cloned. Furthermore, relative expression of EGF mRNA has not been well characterized during trophoblast elongation, implantation, and early development of the placenta (D 10 to D 40). As a first step in determining whether EGF is the gene responsible for the uterine capacity QTL, the objectives of this study were to clone the full length cDNA for EGF precursor and determine changes in expression in EGF mRNA during early pregnancy.

\section{Materials and methods}

\subsection{Cloning of the porcine EGF precursor cDNA}

The cloning strategy and clones of pig EGF precursor obtained in this experiment are illustrated schematically in Fig. 1. From uterine endometrium of D 13 and D 30 pregnant gilts, total RNA was isolated using the RNeasy kit (Qiagen, Santa Clarita, CA). The list of forward and reverse primers at different cloning stages is indicated in Table 1. To obtain the initial clone, $2 \mu \mathrm{g}$ of total RNA was used for reverse-transcription (RT) with reverse primer 2 , and then $1 \mu \mathrm{l}$ of the resultant product was amplified by PCR with all combinations of the forward and reverse primers for the initial clone. Primer design was based on the known porcine cDNA sequence [11]. A $327 \mathrm{bp} \mathrm{PCR} \mathrm{product} \mathrm{amplified} \mathrm{with} \mathrm{forward} \mathrm{primer} 2$ and reverse primer 2 was cloned into pCRII vector (Invitrogen, Carlsbad, CA) as the initial clone and was subsequently sequenced. Forward primer 2 and reverse primer 2, based on the initial clone sequence, were used to screen the "Meat Animal Research Center 2 PIG" porcine expressed sequence tag (EST) library (Fahrenkrug et al., manuscript in preparation). Iterative screening of the EST library revealed a partial 3342 bp EGF precursor clone containing the 3 ' end of the EGF cDNA. A part of the missing 5' region of the EGF cDNA was obtained 


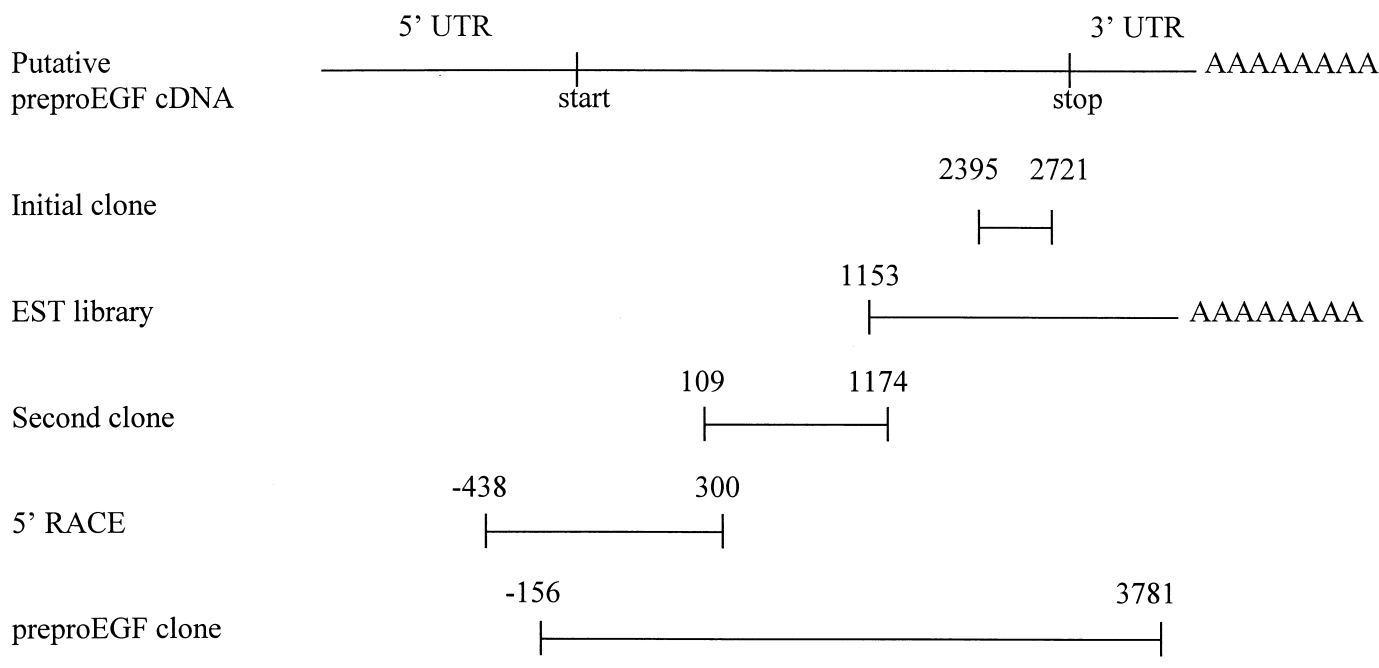

Fig. 1. The cloning strategy and clones of pig epidermal growth factor (EGF) precursor obtained in this experiment are illustrated schematically. Initially, a 329-bp clone was obtained and used to screen the expressed sequence tag (EST) library. Then, 1066-bp and 739-bp clones of further 5' sequences were obtained by reverse transcription-PCR(RT-PCR) and $5^{\prime}$ rapid amplification of cDNA ends (RACE), respectively. Finally, the entire coding sequence of pig preproEGF including portions of $5^{\prime}$ and $3^{\prime}$ untranslated region (UTR) was confirmed.

by RT-PCR. Total RNA ( $2 \mu \mathrm{g}$ ) was used for RT with reverse primer 1 . Then, $1 \mu \mathrm{l}$ of the resultant product was amplified by PCR with the combination of four forward primers (forward primer 3-6) based on the human EGF cDNA sequence and two reverse primers (reverse primer 3-4) based on the porcine EGF cDNA sequence. The 1066 bp product obtained after amplification with forward primer 5 and reverse primer 3 was cloned into pCRII vector and sequenced. This clone encoded for amino acids 37-391. The remaining 5' region was obtained by $5^{\prime}$ rapid amplification of cDNA ends (RACE) following a previously reported procedure [12]. All combinations of the forward (XBAcom and forward primer 7) and reverse primers (reverse primer 5-8) were used for PCR. Forward primer 7 and reverse primers 5 and 6 were designed based on the human sequence, and reverse primer 7 and 8 were designed based on the porcine sequence. The resulting products were then further amplified by PCR with forward primer 7 and reverse primer 8 . The resultant 739 bp product was cloned into pCRII vector. At least three separate clones for each cDNA were sequenced in both directions. Finally, the full-length clone was obtained by RT-PCR using primers for preproEGF, which were designed to amplify the entire coding region. Again, total RNA ( $2 \mu \mathrm{g})$ was used for RT with reverse primer 9. Then $1 \mu \mathrm{l}$ of the resultant product was amplified by PCR with the combination of forward primers 8 and 9, and reverse primers 9 and 10, designed based on the porcine EGF cDNA sequences. The product amplified with forward primer 8 and reverse primer 9 was further amplified with the nested forward and reverse primers. Then the resultant $3937 \mathrm{bp}$ product was cloned into pCRII vector and sequenced. 
Table 1

Primers used in the characterization of the preproEGF cDNAs

\begin{tabular}{|c|c|c|}
\hline Stage & Primer & Sequence \\
\hline \multirow[t]{6}{*}{ Initial } & Forward & \\
\hline & 1 & GGTCGTGGGAAAGATCTGAG \\
\hline & 2 & TGGAGTAATGCCAGTGGACAC \\
\hline & Reverse & \\
\hline & 1 & CATGTGCAGGTGTAGTTTCCC \\
\hline & 2 & СCCATCTCCCTGGTAGCCTTCC \\
\hline \multirow[t]{8}{*}{ Second } & Forward & \\
\hline & 3 & GTCTCTCAGCACCGCAGCAC \\
\hline & 4 & GGAGCTGTCCTGAAGGTACTCTCG \\
\hline & 5 & GGGAATTCTACTTGTGTGGGTCC \\
\hline & 6 & GGTGGTGGATGCTGGTGTCTC \\
\hline & Reverse & \\
\hline & 3 & CATCAGGGAGCAGAACAAATC \\
\hline & 4 & TCAGACACATTGCTTGGGC \\
\hline \multirow[t]{8}{*}{ 5' RACE } & Forward & \\
\hline & XBAcom & AACGACATTGCCTGACTTGAC \\
\hline & 7 & ТСТССАТАТТTСТTСТTТСАGСССC \\
\hline & Reverse & \\
\hline & 5 & CCAGCATCCACCACCAATTG \\
\hline & 6 & CTTTGCAAAAGTTGTCTTTCTAAATCCAC \\
\hline & 7 & GCCTTGTCCCATTCAGAAAAAC \\
\hline & 8 & TGCCTTGTCCCATTCAGAAAAAC \\
\hline \multirow[t]{8}{*}{ preproEGF } & Forward & \\
\hline & 8 & TCTCСАTATTTCTTCTTTCAGCCCC \\
\hline & 9 & TGAAATTTGTCATAAGGGTGTCAGG \\
\hline & Reverse & \\
\hline & 9 & GATTTCTTCTGGGGCTGTAGG \\
\hline & 10 & ATGAGTTACCGAGTGATTCTCCC \\
\hline & Nested forward & AGAAGGAGCTGTAGAGGGCAAG \\
\hline & Nested reverse & CTTTGATGCTGAGTTAGTGATTAGTC \\
\hline
\end{tabular}

\subsection{Northern blotting}

Northern blot analysis was performed using $20 \mu \mathrm{g}$ of total RNA from endometrium of D 10,13 , and 15 cyclic and D 10,13, 15, 20, 30, and 40 pregnant White crossbred gilts ( $n=$ 3 to 5 each). Total RNA was electrophoresed in 1.5\% agarose gels prepared in MOPS (3-[N-morpholino] propane-sulfonic acid)/formaldehyde buffer; the gels were then blotted onto Gene Screen membrane (NEN, Life Science Products, Boston, MA). Intactness of RNA and approximately equal gel loading were assessed [13] visually using ethidium bromide stained ribosomal RNA bands (Fig. 4). Probe was generated by T7 RNA polymerase using the MAXIscript kit (Ambion, Austin, TX) in the presence of $\left[{ }^{32} \mathrm{P}\right] \mathrm{UTP}$ using a 3342-bp partial cDNA clone of EGF precursor obtained from the EST library as the template. Membranes were hybridized with ULTRAhyb (Ambion, Austin, TX) containing $1 \times 10^{6}$ cpm radiolabeled probe per milliliter at $65^{\circ} \mathrm{C}$ overnight. Then the membranes were washed twice with $2 \times \mathrm{SSC}, 0.1 \% \mathrm{SDS}$ at $65^{\circ} \mathrm{C}$, and then with $0.1 \times \mathrm{SSC}, 0.1 \% \mathrm{SDS}$ at $65^{\circ} \mathrm{C}$, and subjected to autoradiography. 


\subsection{Statistical analysis}

Relative expression of EGF precursor mRNA was determined by densitometry and results were analyzed by ANOVA using the General Linear Models procedure of the statistical analysis system (SAS Institute, Inc., Cary, NC). The model included effects of status, day of the cycle or pregnancy, and the status-by-day interaction. However, no effect of status or status-by-day interaction was obtained, so these effects were dropped from the model. Day effects were then more fully evaluated using a set of orthogonal contrasts. Contrasts were 1) D 10 versus D 13; 2) D 10 and 13 combined versus D 15; 3) D 10, 13, and 15 combined versus D 20; 4) D 10, 13, 15, and 20 combined versus D 30; 5) D 10, 13, 15, 20, and 30 combined versus D 40 .

\section{Results}

\subsection{Cloning of porcine EGF precursor}

Nucleotide sequences and predicted amino acid sequences for putative porcine EGF precursor (Genebank Acc. No AF336151) are shown in Fig. 2. Alignment of the EGF precursor cDNA sequence with the human EGF precursor cDNA sequence indicates that the $5^{\prime}$ end of the porcine sequence starts at $16 \mathrm{bp}$ of the reported human preproEGF cDNA sequence [14]. It has a long open reading frame of 3642 bp that encodes 1214 amino acids compared to $3621 \mathrm{bp}$ and 1207 amino acids for human EGF precursor and $3651 \mathrm{bp}$ and 1217 amino acids for mouse EGF precursor. The $5^{\prime}$ and $3^{\prime}$ untranslated regions (UTR) of cDNA were 438 and $549 \mathrm{bp}$, respectively. The sequence identity of the 5' UTR of porcine EGF precursor with the $5^{\prime}$ UTR from mouse, rat, and human ranged from 58 to $77 \%$. The sequence identity of $3^{\prime}$ UTR of EGF precursor cDNA with the 3' UTR of the other three species ranged from 62 to $79 \%$. Though conserved among species, multiple sequence alignment showed no consensus region in either the $5^{\prime}$ UTR or $3^{\prime}$ UTR except a consensus polyadenylation signal of AATAAA located in the $3^{\prime}$ UTR 16 bp upstream from the polyA tail.

Percent identities between the amino acid sequences of pig, human [14], mouse [15], and rat [16] EGF precursors are shown in Table 2. Pig EGF precursor sequence is more homologous to human than to either mouse or rat. The encoded amino acid sequence of porcine EGF precursor cDNA is aligned with those of human, mouse, and rat EGF precursors in Fig. 3. Underlined porcine sequences are the regions first reported in this study, including the 5'-UTR, EGF-like modules 1 and 2 (8 nucleotides of EGF-like module 2 were reported previously, [11]), cytoplasmic domain (4 nucleotides of the cytoplasmic domain were reported previously, [11]), and $3^{\prime}$-UTR with poly A tail. Among the four species, the amino acid identity for the EGF-like module I and II are 66 and $93 \%$, respectively. The mature EGF peptide, as reported previously [10], is indicated in bold letters. 


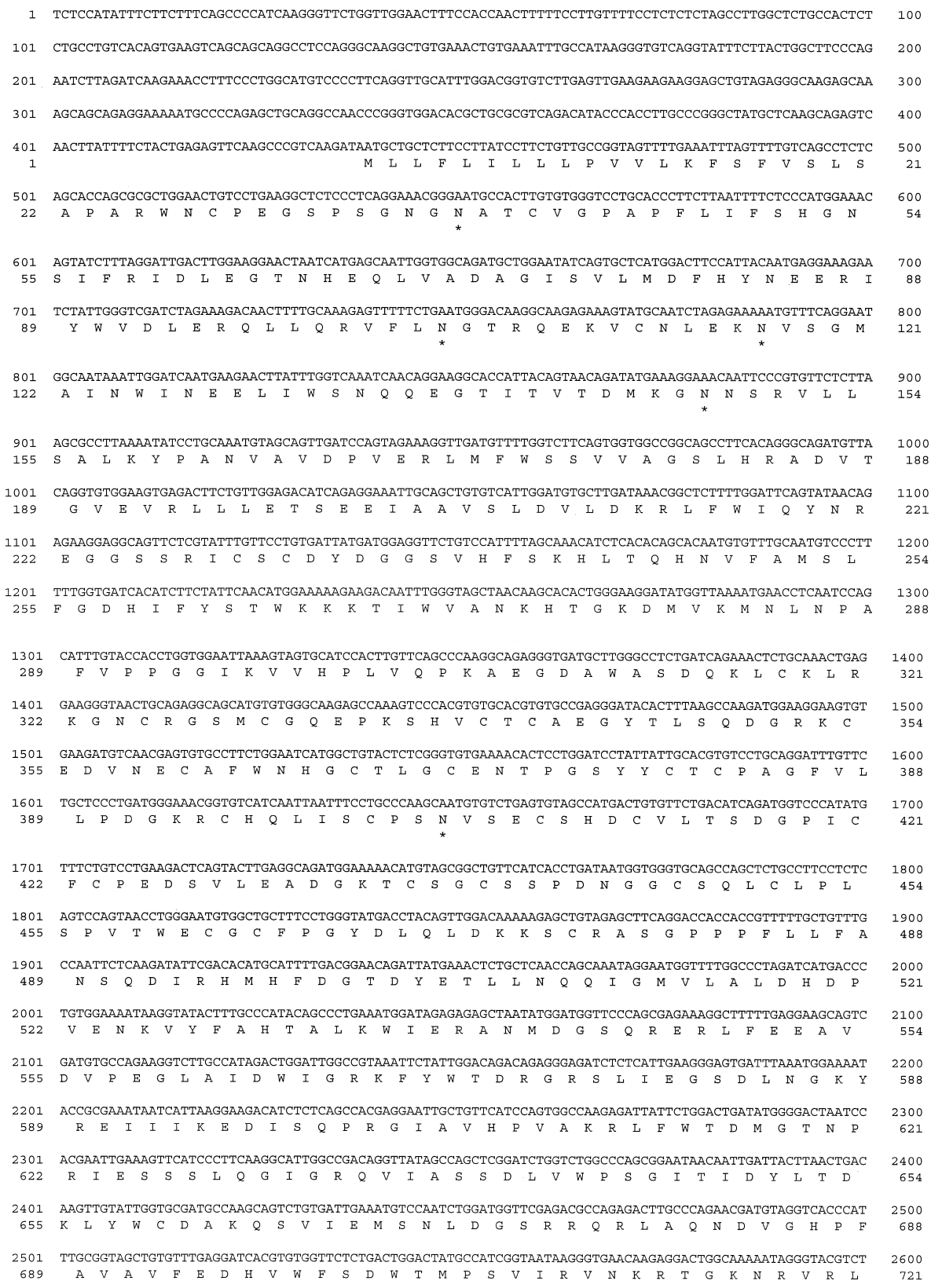

Fig. 2. Nucleotide sequence and predicted amino acid sequence for putative porcine epidermal growth factor precursor is shown. Seven ATTTA repeat sequences are underlined. A consensus polyadenylation signal of AATAAA is shown in bold letters. Possible sites for Asn-linked glycosylation are indicated with *. 


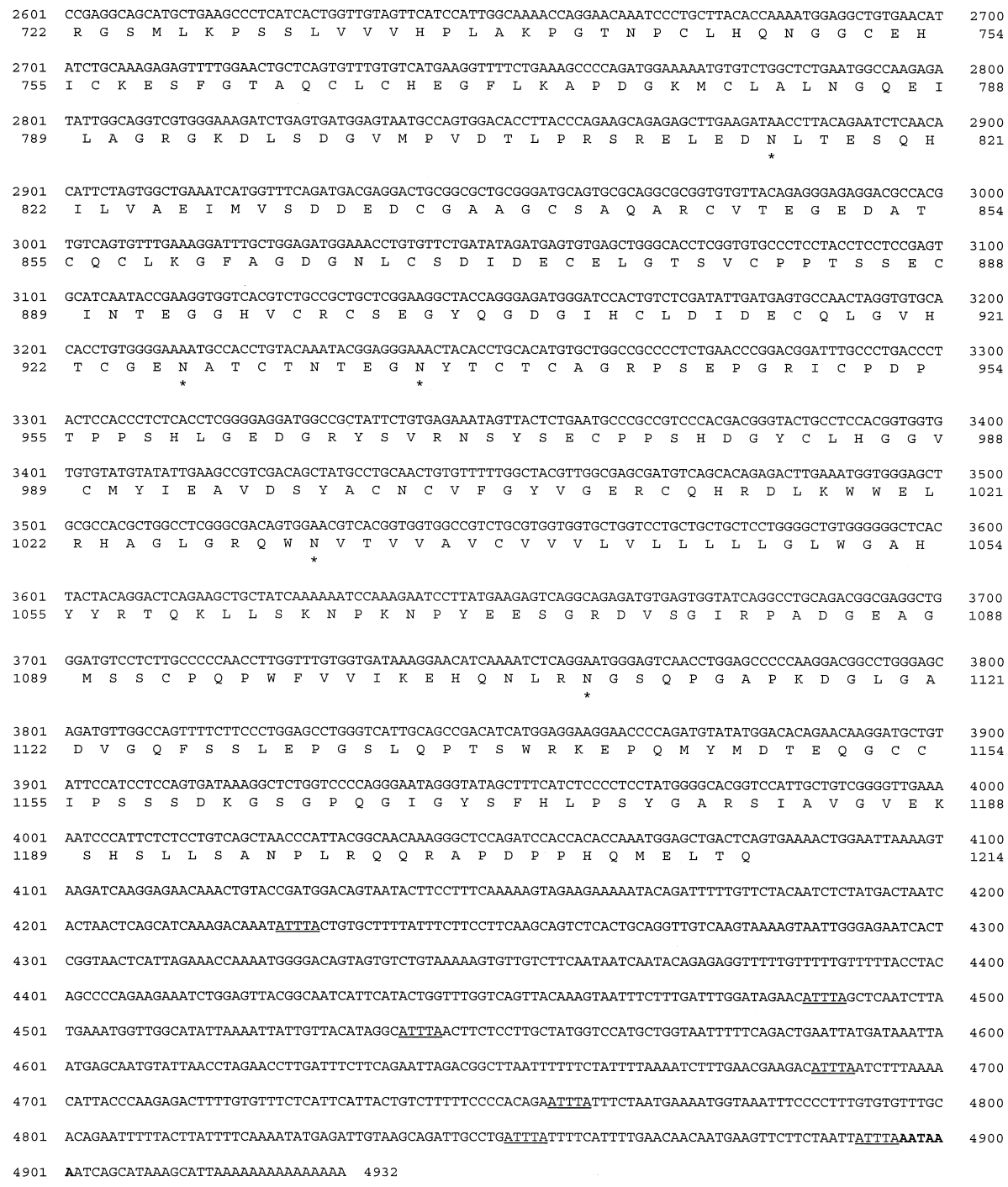

Fig. 2. (continued)

Table 2

Percent identities between the amino acid sequences of the pig, human, mouse and rat preproepidermal growth factor (EGF)

\begin{tabular}{llll}
\hline & Human & Rat & Mouse \\
\hline Pig & 81 & 67 & 66 \\
Mouse & 67 & 79 & \\
Rat & 68 & & \\
\hline
\end{tabular}



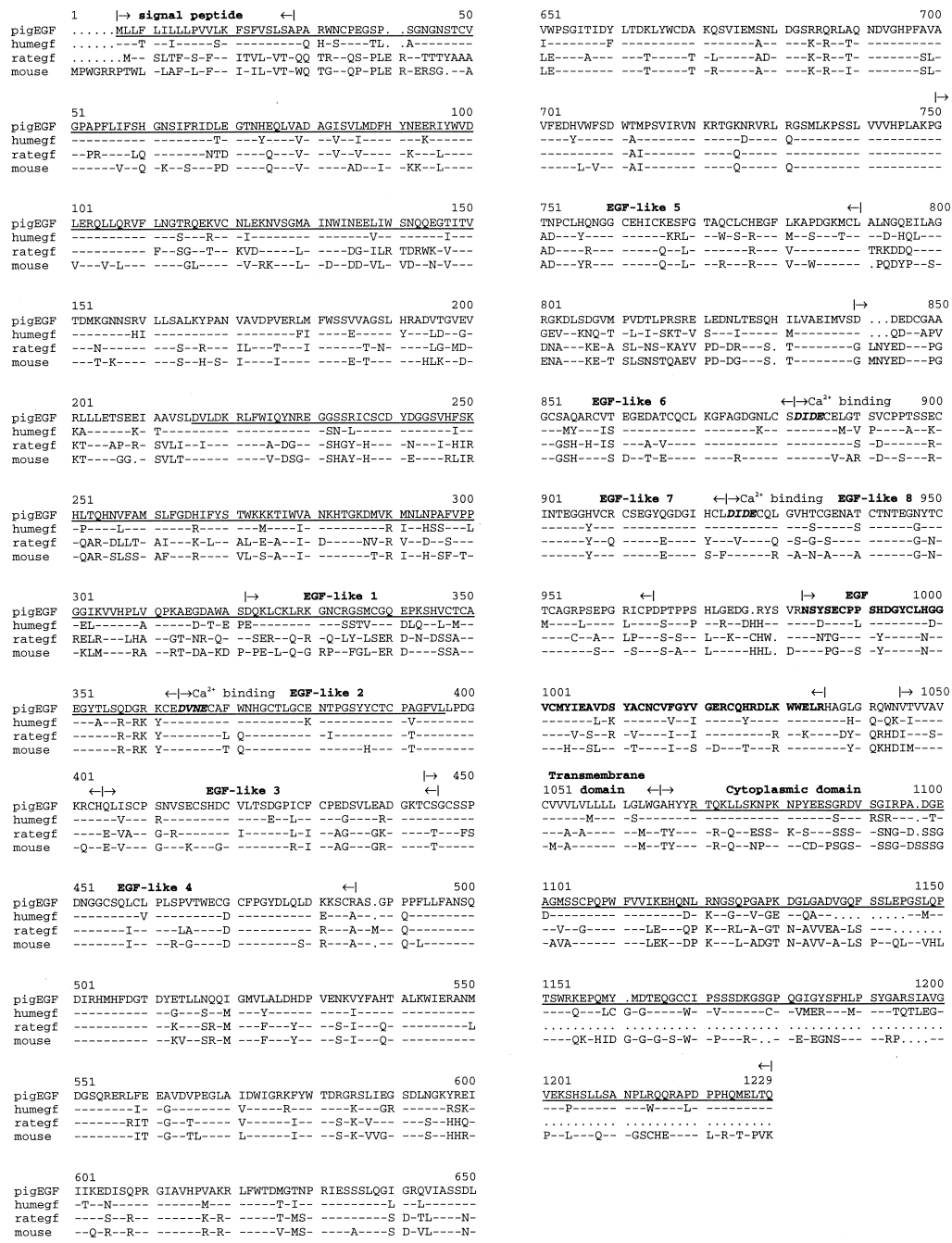

Fig. 3. The similarity between the predicted amino acid sequences for putative porcine epidermal growth factor (EGF) precursor compared with human, rat, and mouse sequences is shown. Underlined porcine sequences are the regions first reported in this study. Bold letters are the coding region corresponding to the mature EGF. The beginning $(\mid \rightarrow)$ and the ending $(\leftarrow \mid)$ of each domain are shown. Calcium binding consensus sequences are shown in bold and italicized characters.

\subsection{Northern blotting}

A representative autoradiograph of a Northern blot of endometrial total RNA probed with $\left[{ }^{32} \mathrm{P}\right]$ labeled EGF cRNA is shown in Fig. 4 along with an ethidium bromide stained agarose gel. Least-square means of densitometry units ( \pm standard error means) for EGF precursor mRNA in endometrium during the estrous cycle and pregnancy are illustrated in Fig. 4C. EGF mRNA expression decreased significantly from $\mathrm{D} 13$ to $15(\mathrm{P}=0.04)$ of the cycle and pregnancy and from $\mathrm{D} 30$ to $40(\mathrm{P}=0.01)$ of pregnancy. These findings show that EGF mRNA expression is temporally regulated. 

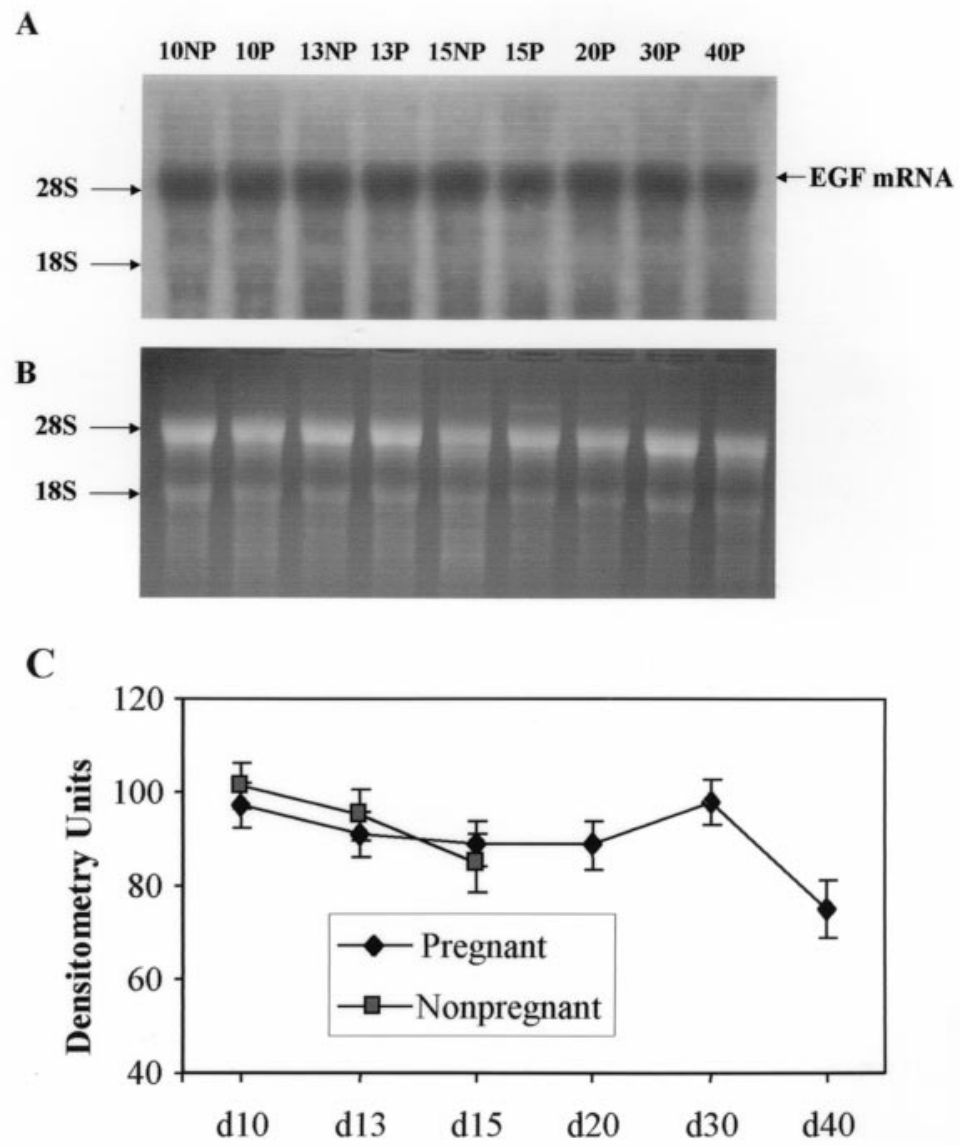

Fig. 4. Representative autoradiograph of Northern blot (A) and photograph of agarose gel loaded with total cellular RNA $(20 \mu \mathrm{g})$ from endometrium of nonpregnant (NP) gilts on D 10, 13, and 15, and pregnant (P) gilts on D 10, 13, 15, 20, 30, and 40 (B). Arrows indicate $28 \mathrm{~S}$ and $18 \mathrm{~S}$ ribosomal bands. Epidermal growth factor (EGF) mRNA band (approximately $5-\mathrm{kb}$ ) is also indicated. Least-square means ( \pm standard error means) of densitometry units for EGF precursor mRNA in endometrium during estrous cycle and pregnancy are illustrated (C). EGF mRNA expression tends to decrease gradually during the estrous cycle and pregnancy with significant drops from $\mathrm{D} 13$ to $15(\mathrm{P}=0.04)$ and from $\mathrm{D} 30$ to $40(\mathrm{P}=0.01)$. These findings show that EGF mRNA expression is temporally regulated.

\section{Discussion}

This is the first reported cloning of the full coding region for the porcine EGF precursor. The coding sequence of porcine EGF precursor is most similar to human EGF precursor. It is much less homologous to the rodent EGF sequence as reported previously using partial EGF precursor sequence [11]. Interestingly, amino acids within the mature peptide are not more conserved than the rest of the coding sequence. Highlighting of the altered amino acids on a three-dimensional view of mature human EGF (not shown) indicated that the differences appear to be distributed uniformly over the surface of the peptide. This may reflect the lack 
of specificity of the EGF receptor, which can be activated by many ligands of the EGF family including transforming growth factor- $\alpha$ [17].

The high amino acid sequence identity in the nonEGF portions of the EGF precursor suggests that these regions may play a role in the processing or function of EGF. The role of nonEGF portions has been speculated based on a comparison between mouse EGF precursor and the human low density lipoprotein (LDL) receptor [18-20]. The region of the mouse EGF precursor (amino acids 22-392) between the signal peptide and the region homologous to human LDL receptor might constitute the ligand binding domain [14]. The cytoplasmic domain of mouse EGF precursor (amino acids 1058-1207) might function in receptor mobilization and internalization [14]. However, the lack of conservation of the cytoplasmic domain of EGF precursor argues against this region being functional. The functional significance of these domains in EGF precursor is not clear. EGF precursor has 8 EGF-like modules in addition to EGF [14]. The EGF-like modules may be involved in protein-protein interactions [21]. A subclass of EGF-like modules exhibits the consensus sequence Cys-X-Asp/Asn-X-X-X-X-Tyr/Phe-X-Cys required for the postribosomal hydroxylation of the Asp/Asn residue [22]. Only EGF-like modules 2, 7, and 8 of human EGF precursor contain the consensus sequence for Asp/Asn hydroxylation. All three of these EGF-like modules have a calcium binding site with the consensus sequence of Asp-Ile/ValAsp-Glu. Studies on human clotting factors have also shown that EGF-like modules bind $\mathrm{Ca}^{2+}$ [23-25]. Synthetic EGF-like module 2 binds $\mathrm{Ca}^{2+}$ with low affinity similar to other isolated EGF-like modules. EGF-like module 7, when part of the intact protein, binds $\mathrm{Ca}^{2+}$ with higher affinity than that of isolated EGF-like modules [22]. Porcine EGF precursor amino acid sequences for EGF-like modules 2, 7, and 8 are conserved in corresponding sites as indicated in Fig. 3; thus, the putative Asp/Asn residue hydroxylation sites and potential $\mathrm{Ca}^{2+}$ binding sites are likely to be functional. This is of interest as estradiol secreted by the conceptus stimulates a rapid release of calcium into the uterine lumen [26] at the time of trophoblast elongation on D 12. The interaction of EGF precursor with calcium warrants further study.

Seven ATTTA repeat sequences are located in the $3^{\prime}$-UTR (compared to four repeats in human and five repeats in mouse and rat). These sequences have been reported to influence the turnover of mRNA [27]. The higher number of ATTTA repeats in porcine sequence may increase the rate of degradation of EGF precursor mRNA. Disruption of one or more of the ATTTA sequences using site directed mitogenesis could help determine whether the ATTTA sequences are involved in the turnover of the mRNA.

Human EGF precursor sequence has nine possible sites for Asn-linked glycosylation and all are located in the region that would be predicted to project from the cell surface if it were anchored in the membrane [14]. Porcine EGF precursor sequence has seven of ten potential sites for Asn-linked glycosylation in corresponding positions, while in the mouse only two of the six sites are in corresponding positions [14].

Glutamine (amino acid 634) coded by codon CAG in the porcine EGF precursor sequence was obtained from both the EST library and the 3937-bp preproEGF clone, while arginine coded by CGG was reported previously using RNA from Danish Landrace kidney [11]. This possible polymorphism is outside the EGF-like modules. Therefore, it is not likely to change the function of EGF precursor. 
Growth factors, including EGF, in the uterine fluid may regulate conceptus or endometrial development during early pregnancy. At the time of trophoblast elongation on D 12 , the conceptus secretes estradiol, which stimulates a rapid release of calcium into the uterine lumen [26]. The expression of EGF in mice [28] and EGF receptor in rats [29] are stimulated by estrogens.

Elevated EGF precursor mRNA expression on D 30 and the drop in expression on D 40 of pregnancy are correlated with estradiol concentrations in uterine vein [30]. However, the EGF precursor mRNA expression pattern in this study, which is elevated from D10 to 13 and decreased from D 13 to D 15, is not correlated with the luminal estradiol profiles of either cyclic or pregnant gilts [26]. The role of EGF mRNA expression in endometrial function or conceptus development is not known. Expression of EGF mRNA is high previous to and during conceptus elongation and decreases as elongation nears completion (D 15). Thus, EGF may play a role in conceptus elongation. Between D 30 and D 40 of pregnancy, EGF mRNA expression is associated with placental areolae development. Areolae develop over the openings of the uterine glands between D 30 and D 40, and are responsible for uptake of uterine products. Thus it is possible that the changes in EGF mRNA expression may play a role in some aspects of areolae development. A complicating factor in any proposed role for EGF during this period is that the EGF precursor requires proteolytic processing to generate the mature peptide. EGF precursor has been reported to be cleaved by kallikrein, a serine protease [31]. Both kallikrein gene expression and kallikrein activity have been observed in endometrium in swine [32]. Thus, kallikrein may be involved in the processing of EGF precursor, and processing likely influences the role of EGF in both conceptus and endometrial development. Further study is required to determine how the EGF precursor is processed, how proteolytic enzymes control EGF in the uterine environment, and the role of EGF in conceptus or endometrial development.

Wollenhaupt et al. [2] have shown by RT-PCR that EGF mRNA expression in the endometrium was higher on D 6 than D 1 of cyclic and pregnant pigs by RT-PCR. Because our results do not cover the same period, it is difficult to compare.

In conclusion, the full coding region for the porcine EGF precursor cDNA is reported. The high amino acid sequence identity in the nonEGF portions of the EGF precursor suggests that these regions may play a role in the processing or function of EGF. Northern blot analysis shows that EGF mRNA expression is temporally regulated during the cycle and early pregnancy; this pattern of gene expression may be important during early conceptus development, thus contributing to the uterine capacity.

\section{References}

[1] Vaughan TJ, James PS, Pascall JC, Brown KD. Expression of the genes for TGF alpha, EGF and the EGF receptor during early pig development. Development 1992;116:663-9.

[2] Wollenhaupt K, Einspanier R, Gabler C, Schneider F, Kanitz W, Brussow KP. Identification of the EGF/EGF-R system in the oviduct and endometrium of pigs in early stages of pregnancy and early conceptus. Exp Clin Endocrinol Diabetes 1999;107:530-8.

[3] Brigstock DR, Kim GY, Steffen CL, Liu A, Vegunta RK, Ismail NH. High molecular mass forms of epidermal growth factor in pig uterine secretions. J Reprod Fertil 1996;108:313-20. 
[4] Wollenhaupt K, Tiemann U, Einspanier R, Schneider F, Kanitz W, Brussow KP. Characterization of the epidermal growth factor receptor in pig oviduct and endometrium. J Reprod Fertil 1997;111:173-81.

[5] Christenson RK, Leymaster KA, Young LD. Justification of unilateral hysterectomy-ovariectomy as a model to evaluate uterine capacity in swine. J Anim Sci 1987;65:738-44.

[6] Christenson RK, Leymaster KA. Effects of selection for ovulation rate or uterine capacity on gravid uterine, farrowing, and weaning traits in swine. J Anim Sci 2000;78(Suppl. 1):202.

[7] Leymaster KA, Christenson RK. Direct and correlated responses to selection for ovulation rate or uterine capacity in swine. J Anim Sci 2000;78(Suppl. 1):68.

[8] Rohrer GA, Ford JJ, Wise TH, Vallet JL, Christenson RK. Identification of quantitative trait loci affecting female reproductive traits in a multigeneration Meishan-White composite swine population. J Anim Sci 1999;77:1385-91.

[9] Mendez EA, Messer LA, Larsen NJ, Robic A, Rothschild MF. Epidermal growth factor maps to pig chromosome 8. J Anim Sci 1999;77:494-5.

[10] Pascall JC, Jones DS, Doel SM, Clements JM, Hunter M, Fallon T, Edwards M, Brown KD. Cloning and characterization of a gene encoding pig epidermal growth factor. J Mol Endocrinol 1991;6:63-70.

[11] Jorgensen PE, Jensen LG, Sorensen BS, Poulsen SS, Nexo E. Pig epidermal growth factor precursor contains segments that are highly conserved among species. Scand J Clin Lab Invest 1998;58:287-98.

[12] Vallet JL, Smith TPL, Sonstegard T, Pearson PL, Christenson RK, Klemcke HG. Isolation of complementary deoxyribonucleic acids encoding putative secreted and membrane-bound folate binding proteins from endometrium of swine. Biol Reprod 1999;61:372-9.

[13] Ivell R. A question of faith-or the philosophy of RNA controls. J Endocrinol 1998;159:197-200.

[14] Bell GI, Fong NM, Stempien MM, Wormsted MA, Caput D, Ku LL, Urdea MS, Rall LB, Sanchez-Pescador R. Human epidermal growth factor precursor: cDNA sequence, expression in vitro and gene organization. Nucleic Acids Res 1986;14:8427-46.

[15] Scott J, Urdea M, Quiroga M, Sanchez-Pescador R, Fong N, Selby M, Rutter WJ, Bell GI. Structure of a mouse submaxillary messenger RNA encoding epidermal growth factor and seven related proteins. Science 1983;221:236-40.

[16] Saggi SJ, Safirstein R, Price PM. Cloning and sequencing of the rat preproepidermal growth factor cDNA: comparison with mouse and human sequences. DNA Cell Biol 1992;11:481-7.

[17] Carpenter G, Zendegui JG. Epidermal growth factor, its receptor, and related proteins. Exp Cell Res 1986;164:1-10.

[18] Russell DW, Schneider WJ, Yamamoto T, Luskey KL, Brown MS, Goldstein JL. Domain map of the LDL receptor: sequence homology with the epidermal growth factor precursor. Cell 1984;37:577-85.

[19] Yamamoto T, Davis CG, Brown MS, Schneider WJ, Casey ML, Goldstein JL, Russell DW. The human LDL receptor: a cysteine-rich protein with multiple Alu sequences in its mRNA. Cell 1984;39:27-38.

[20] Sudhof TC, Goldstein JL, Brown MS, Russell DW. The LDL receptor gene: a mosaic of exons shared with different proteins. Science 1985;228:815-22.

[21] Campbell ID, Bork P. Epidermal growth factor-like modules. Curr Opin Struct Biol 1993;3:385-92.

[22] Valcarce C, Bjork I, Stenflo J. The epidermal growth factor precursor. A calcium-binding, $\beta$-hydroxyasparagine containing modular protein present on the surface of platelets. Eur J Biochem 1999;260:200-7.

[23] Leonard BJ, Clarke BJ, Sridhara S, Kelley R, Ofosu FA, Blajchman MA. Activation and active site occupation alter conformation in the region of the first EGF domain of human factor VII. J Biol Chem 2000;275:34894-900.

[24] Selander-Sunnerhagen M, Ullner M, Persson E, Teleman O, Stenflo J, Drakenberg T. How an epidermal growth factor (EGF)-like domain binds calcium. High resolution NMR structure of the calcium form of the NH2-terminal EGF-like domain in coagulation factor X. J Biol Chem 1992;267:19642-9.

[25] Rao Z, Handford P, Mayhew M, Knott V, Brownlee GG, Stuart D. The structure of a Ca(2+)-binding epidermal growth factor-like domain: its role in protein-protein interactions. Cell 1995;82:131-41.

[26] Geisert RD, Zavy MT, Moffatt RJ, Blair RM, Yellin T. Embryonic steroids and the establishment of pregnancy in pigs. J Reprod Fertil Suppl 1990;40:293-305. 
[27] Shaw G, Kamen R. A conserved AU sequence from the 3' untranslated region of GM-CSF mRNA mediates selective mRNA degradation. Cell 1986;46:659-67.

[28] Huet-Hudson YM, Chakraborty C, De SK, Suzuki Y, Andrews GK, Dey SK. Estrogen regulates the synthesis of epidermal growth factor in mouse uterine epithelial cells. Mol Endocrinol 1990;4:510-23.

[29] Mukku VR, Stancel GM. Regulation of epidermal growth factor receptor by estrogen. J Biol Chem 1985;260:9820-4.

[30] Knight JW, Bazer FW, Thatcher WW, Franke DE, Wallace HD. Conceptus development in intact and unilaterally hysterectomized-ovariectomized gilts: interrelations among hormonal status, placental development, fetal fluids and fetal growth. J Anim Sci 1977;44:620-37.

[31] Jahnke GD, Chao J, Walker MP, Diaugustine RP. Detection of a kallikrein in the mouse lactating mammary gland: a possible processing enzyme for the epidermal growth factor precursor. Endocrinology 1994;135: 2022-9.

[32] Vonnahme KA, Malayer JR, Spivey HO, Ford SP, Clutter A, Geisert RD. Detection of kallikrein gene expression and enzymatic activity in porcine endometrium during the estrous cycle and early pregnancy. Biol Reprod 1999;61:1235-41. 